33 Watkins LL, Blumenthal JA, Carney RM. Association of anxiety with reduced baroreflex cardiac control in patients after acute myocardial infarction. Am Heart J 2002; 143: 460-6.

34 Cameron OG, Smith CB, Lee MA, Hollingsworth PJ, Hill EM, Curtis GC. Adrenergic status in anxiety disorders: platelet alpha 2-adrenergic receptor binding, blood pressure, pulse, and plasma catecholamines in panic and generalized anxiety disorder patients and in normal subjects. Biol Psychiatry 1990; 28: 3-20.

35 Pitsavos C, Panagiotakos DB, Papageorgiou C, Tsetsekou E, Soldatos C Stefanadis $C$. Anxiety in relation to inflammation and coagulation markers, among healthy adults: the ATTICA study. Atherosclerosis 2006; 185: 320-6.

36 Bonnet F, Irving K, Terra JL, Nony P, Berthezène F, Moulin P. Anxiety and depression are associated with unhealthy lifestyle in patients at risk of cardiovascular disease. Atherosclerosis 2005; 178: 339-44.
37 Benninghoven $D$, Kaduk A, Wiegand $U$, Specht T, Kunzendorf S, Jantschek G. Influence of anxiety on the course of heart disease after acute myocardial infarction - risk factor or protective function? Psychother Psychosom 2006 75: $56-61$.

38 Kuhl EA, Fauerbach JA, Bush DE, Ziegelstein RC. Relation of anxiety and adherence to risk-reducing recommendations following myocardial infarction. Am J Cardiol 2009; 103: 1629-34.

39 Mykletun A, Bjerkeset O, Øverland S, Prince M, Dewey M, Stewart R. Levels of anxiety and depression as predictors of mortality: the HUNT study. Br J Psychiatry 2009; 195:118-25.

40 Davidson JR. First-line pharmacotherapy approaches for generalized anxiety disorder. J Clin Psychiatry 2009; 70: 25-31.

\title{
The diet of King George III
}

\section{Rafael Euba}

The following are extracts from an article in The Times, entitled 'On His Majesty's Disorder'. It was published in November 1788, at the height of the worst episode in King George III's mental illness. The writer ('Brit. et Pat. Amicus') addresses his bitter criticism of the treatment the King is receiving to Sir George Baker MD, His Majesty's physician. Capital letters, italics and some archaic spellings are reproduced here as they appear in the original text.

(. . .) Great care, Sir George, must be taken to remedy a violent disorder when it is once got into the head and to prevent the delirium which occations [sic] a temporary alienation of the mind and may (but God forbid it) produce a fixed frenzy in the brain, so difficult it is to be dislodged. A dreadful event! And yet it would be cruel to call it INSANITY, since it is not a natural incapacity of the mind, but one unhappily acquired by perhaps too much confidence in the faculty.

(. . ) Sir George, if the nation, in their anxiety and solicitude for their Sovereign, see, with astonishment and concern, the treatment of His Majesty's disorder, by which a life most dear to his subjects and most important to Europe, has been endangered, what will they think of so strange a regimen?

'Tea', which has no virtue, 'Bread and Butter,' which has little nourishment, and 'Potatoes', fit only for animals, offer together a specimen of the sagacity of the faculty.

Without enquiring whether the King's disorder is natural or acquired - that is, whether the FEVER is the cause of his complaint or the effect of his treatment, I will venture to pronounce that, in the present situation of the Royal Patient, weak coffee is better for the bowels, that have been greatly disorder by a violent cold, than nervous and windy tea - that soft toast and butter is more nourishing and proper than bread and butter - and that bread pudding, or batter pudding, or ground rice pudding, the former in particular, is light, nourishing, and infinitely better than 'potatoe-pudding.

Sir George, would not a little boiled chicken, a little boiled veal, and weak veal broth, with a little wine and water occasionally, be a better diet than the rubbish we are told is prescribed by his Majesty's physicians? (. . . )

For God's sake, Sir George, if the faculty did not know how to treat the disorder of a Prince with an excellent constitution, and the best habits of body and mind, without endangering his valuable life, let the world see that you have, at least, sense enough to know when it is supposed he is recovering from so great a danger, what it is wholesome and good for his Majesty to eat.

The Times, 29 November 1788. 